\title{
Przemysław Wiatrowski, Morfologiczne i leksykalne wyktadniki negatywnych emocji w „Przewodniku Katolickim” z lat 1895-2005, Wydawnictwo Rys, Poznań 2010, ss. 367
}

Książka Przemysława Wiatrowskiego sytuuje się w kręgu badań nad ekspresywnością w języku, jednocześnie, ze względu na materiał badawczy i podjętą problematykę, dotyka również obszarów związanych z językiem prasy oraz z oddziaływaniem nakłaniającej funkcji języka w tym typie tekstów. Nadrzędnym celem badawczym, jaki stawia sobie autor opracowania, jest ,analiza wynotowanych z kart «Przewodnika Katolickiego» faktów językowych służących nadawcom pisma do uzewnętrzniania negatywnych emocji” (s. 16). Przedmiot swoich analiz Przemysław Wiatrowski ogranicza tylko do wykładników emocji negatywnych, co uzasadnia tym, że ,zbiór tych środków jest najbardziej interesujący tak pod względem frekwencyjnym, jak i formalno-semantycznym. Skupienie uwagi jedynie na emocjach o znaku ujemnym zapewni ponadto większą homogeniczność materiałowo-interpretacyjną" (s. 17).

Jednocześnie autor wprowadza także inne ograniczenia związane z interpretacja materiału. Ekscerpcji poddaje tylko morfologiczne oraz leksykalne wskaźniki negatywnych emocji. Wybór ten tłumaczy tym, że „wymienione elementy z jednej strony odznaczają się wyrazistością związaną z ich wysoką frekwencją tekstowa, z drugiej zaś - stanowią zbiór reprezentujący duże zróżnicowanie strukturalne i znaczeniowe" (s. 17).

Ostatecznie autor opracowania stawia sobie następujące szczegółowe cele badawcze:

1) ujawnienie elementów konstytutywnych, kształtujących emocjonalną wartość analizowanych jednostek fleksyjnych, słowotwórczych i leksykalnych;

2) identyfikacja znaczenia emocjonalnego kryjącego się w opisywanych strukturach werbalnych;

3) rozpoznanie przyczyn manifestowania określonych uczuć; 
4) próba odpowiedzi na pytanie o funkcje językowych wykładników negatywnych emocji oraz o ewentualne zmiany, jakie dokonały się w badanym materiale w ciagu 110 lat.

W opisie analizowanych tekstów oraz w określeniu, które $\mathrm{z}$ badanych jednostek fleksyjnych, słowotwórczych i leksykalnych cechują się barwą emocjonalną, autor książki posługuje się metodologią z zakresu semantyki strukturalnej (odwołuje się tu przede wszystkim do analizy semowej, a także do koncepcji pola semantycznego). Słusznie jednak w swoich obserwacjach materiału nie pozostaje obojętny na znaczenie kontekstu, gdyż, jak zauważa we wstępie, „bliższe bądź dalsze otoczenie językowe umożliwia właściwą interpretację znaczeniową nazw uczuć (w tym ich usytuowanie we właściwym polu semantycznym). Pozwala ponadto zrekonstruować aspekty konstytuujące sytuację przeżywania emocji (przede wszystkim uczucie, jego podmiot, obiekt, sprawcę oraz zdarzenie wywołujące uczucie) uzewnętrznianych wszystkimi typami środków językowych" (s. 19).

Omawiana rozprawa ma charakter materiałowo-interpretacyjny. Źródłem analizowanego materiału są wypowiedzi prasowe zamieszczone w „Przewodniku Katolickim” w latach 1895-2005. Pod uwagę brane były przede wszystkim teksty o charakterze publicystycznym (komentarze, artykuły, felietony, reportaże, sylwetki, odpowiedzi na listy), w znacznie mniejszym stopniu gatunki informacyjne i publicystyczno-informacyjne (tutaj rodzi się pokusa, by zbadać językowe wykładniki negatywnych emocji w tekstach informacyjnych, interesujące bowiem byłoby porównanie, jak i w jakim stopniu funkcjonują emocjonalizmy w gatunkach informacyjnych i publicystycznych w prasie konfesyjnej). Ekscerpcji materiału autor dokonał na podstawie czterech roczników pisma, pochodzących z lat: 1895 (52 numery), 1938 (52 numery), 1968 (52 numery), 2005 (52 numery oraz dwa numery specjalne). W sumie oglądowi poddał 3000 tekstów prasowych, z których wynotował 2000 rozbudowanych cytatów zawierających morfologiczne i leksykalne wykładniki negatywnych emocji.

Książka składa się zasadniczo z dwóch części, poprzedzonych dwoma rozdziałami o charakterze wprowadzenia, w których Przemysław Wiatrowski szczegółowo omawia kolejno: przedmiot, cel, metody badań, podstawę materiałową, układ i zawartość pracy oraz przybliża dzieje „Przewodnika Katolickiego”. Część pierwsza, zatytułowana Teoretyczne zaplecze analiz (s. 39-109), poświęcona jest problematyce emocji. Na uznanie zasługuje fakt, że zagadnienie to, tak złożone i obszerne, zostało potraktowane w sposób bardzo skrupulatny i wyczerpujący.

W pierwszym rozdziale autor omawia psychologiczne konteksty emocji. Zwraca tutaj uwagę na problemy związane z eksplikacją terminów „emocja” i „uczucie” oraz wskazuje wybrane modele przebiegu procesów emocjonal- 
nych. Przedstawia również, odwołując się do bogatej literatury przedmiotu, wybrane propozycje klasyfikacji emocji, uwzględniające rozmaite kryteria podziału. Ostatni podrozdział autor poświęcił wybranym zagadnieniom z zakresu charakterystyki i funkcji emocji. Przywołuje między innymi takie właściwości emocji, jak: intensywność, głębokość emocji, ich reaktywny bądź antypacyjny charakter, ekspresja uczuć, szczerość bądź nieszczerość uczuć.

Rozdział drugi części pierwszej dotyczy lingwistycznych opisów emocji. W świetle rozmaitych metod badawczych wykorzystywanych w językowym opisie emocji, czego konsekwencją jest wyraźnie zróżnicowany aparat pojęciowy, autor książki podejmuje niełatwą próbę uporządkowania terminologii i wewnętrznych podziałów w obrębie problematyki ekspresji w językoznawstwie. Szczegółowo wyjaśnia więc takie pojęcia, jak: „ekspresja”, „ekspresywność”, ,językowy znak ekspresywny”, „wykładnik emocji”. W swoim opisie, odwołując się do opracowań rodzimych, np. Stanisława Grabiasa, Teresy Smółkowej, Teresy Skubalanki, Anny Wierzbickiej, sięga także do propozycji Charles'a Bally’ego, Pierre’a Guirauda czy Miroslava Grepla. Ostatecznie, w nawiązaniu do ustaleń Smółkowej, autor pracy przyjmuje węższe rozumienie ekspresji, którą definiuje ,jako proces bezpośredniego (eksplicytnego) lub pośredniego (implicytnego) uzewnętrznienia różnych emocji nadawcy" (s. 65). Ekspresywność z kolei uznaje za właściwość (składnik) znaków wskazującą na uczuciowy stosunek nadawcy do rzeczywistości zewnątrzjęzykowej. W tym kontekście synonimami ekspresywności są dla autora także takie pojęcia, jak: „emocjonalność”, „uczuciowośćc”, „afektywność” oraz „emotywność”. Natomiast językowy znak ekspresywny definiuje jako „każdy element werbalny, który służy zamanifestowaniu (wyrażeniu) emocjonalnego stosunku do prezentowanych w komunikacie osób, rzeczy czy zjawisk" (s. 66). Ponadto przyjmuje istnienie znaków ekspresywnych, w których składnik emocjonalny jest obligatoryjnie wpisany w ich znaczenie, a także takich, w których komponent uczuciowy ma charakter fakultatywny i należy do ich znaczenia pragmatycznego.

W kolejnych podrozdziałach dotyczących lingwistycznych aspektów emocji Przemysław Wiatrowski bardzo szczegółowo omawia problematykę związaną z funkcjonowaniem terminów „emocja” i ,uczucie” oraz z typologią emocji. Na potrzeby swojej pracy przyjmuje stanowisko traktujące powyższe pojęcia jako jednoznaczne, za synonimy tych jednostek uznające takie określenia, jak: przeżycie emocjonalne i przeżycie uczuciowe, natomiast za hiperonimy: przeżycie psychiczne, przeżycie wewnętrzne, stan wewnętrzny, stan psychiczny. Wśród różnorodnych typologii emocji (przywoływanych m.in. za Władysławem Lubasiem, Stanisławem Grabiasem, Aleksym Awdiejewem) na użytek własnych analiz przyjmuje (z niewielkimi modyfikacjami) propozy- 
cję Iwony Nowakowskiej-Kempnej, bazującą przede wszystkim na kryterium związanym z charakterystyką temporalną emocji. Innym ważnym problemem są sposoby uzewnętrzniania emocji. Autor powołuje się tutaj na ustalenia Grabiasa. Na ich podstawie wśród typów ekspresji wyróżnia następujące kategorie: przejawianie uczuć, wyrażanie uczuć oraz komunikowanie o emocjach. Rozdział poświęcony emocjom w języku kończy bardzo szczegółowe omówienie aktualnego stanu badań nad problematyką komunikowania i wyrażania negatywnych emocji.

Na drugą, materiałową część pracy składają się dwa obszerne rozdziały (s. 109-269). Pierwszy z nich zawiera analizę morfologicznych wykładników emocji. W opisie są uwzględniane dwie grupy form wyrazowych - ekspresywizmy fleksyjne i ekspresywizmy słowotwórcze. W grupie pierwszej, zdecydowanie mniej licznej, znajdują się deprecjatywne formy wyrazowe (np. katy, opryszki, żydy) oraz formy liczby mnogiej nazw własnych (Szmule, Gottliby, Staliny). Bardziej rozbudowaną grupę stanowią ekspresywizmy słowotwórcze. Autor wyróżnia wśród nich derywaty rzeczownikowe oraz derywaty przymiotnikowe, przy czym te pierwsze są bardziej zróżnicowane pod względem słowotwórczym - obejmują konstrukcje sufiksalne (np. handelek, synalek, rozmówka, piśmidło, powieścidło, totrzyk itp.), paradygmatyczne (tutaj wskazano tylko dwa leksemy: chłopię i Józio), ujemne (tylko jeden przykład: plotka$r a$ ) oraz komponowane (odnotowano dwie jednostki: zydo-komuna i pornobiznes). W obrębie derywatów przymiotnikowych wynotowane zostały tylko formacje sufiksalne (ubożuchny, stabiutki) oraz złożenia (masońsko-liberalny i oligarchiczno-esbecka).

Znacznie bogatszą grupę stanowią leksykalne wykładniki emocji. Jak pisze autor, jest to „najliczniejszy i jednocześnie najbardziej zróżnicowany zbiór jednostek językowych służących autorom «Przewodnika Katolickiego»do uzewnętrzniania (komunikowania i wyrażania) negatywnych emocji” (s. 179). Wśród leksykalnych wykładników konstytuujących emocje znalazły się tutaj leksemy nazywające emocje oraz ekspresywizmy leksykalne. W grupie pierwszej znalazły się: leksemy nazywające afekty (np. smutny, bolesny, obawa, przerażajacy itp.), leksemy nazywające postawy emocjonalne (jak tęsknić, nie lubić) oraz leksykalne intensyfikatory emocji (bardzo smutny, tak boleśnie). Z kolei w obrębie ekspresywizmów leksykalnych autor wyróżnia eksprsywizmy pierwotne (np. zbir, zbrodniarz, zaprzaniec, sekciarz) oraz ekspresywizmy wtórne (np. kat, najemnik, potwór, zmora).

Ostatnim rozdziałem książki jest Zakończenie, w którym autor podsumowuje wyniki przeprowadzonych analiz i pisze o funkcjach językowych wykładników negatywnych emocji. Do najważniejszych zalicza funkcje: katartyczną, kumulatywną, socjalizująca, autokreacyjną oraz nakłaniająca. Warto 
by tutaj, odnosząc się do zebranego materiału, pokusić się o próbę wskazania, która z wymienionych funkcji dominuje, a które funkcje są jej podległe.

Interesującym dopełnieniem końcowych rozważań jest przyjrzenie się wykładnikom negatywnych emocji w kontekście diachronicznym. Poczynione tutaj uwagi odnoszą się do opisu jakościowego (dotyczącego zewnątrzjęzykowych czynników odpowiedzialnych za pojawienie się reakcji emocjonalnej) i ilościowego (ten opis ma charakter ogólny, ponieważ prowadzone obserwacje obejmowały tylko wybrane roczniki). Ostatnim elementem omawianej książki jest obszerna bibliografia (łącznie 693 pozycje!), która, co należy podkreślić, została podzielona tematycznie na trzy grupy: opracowania historyczne i medioznawcze, opracowania psychologiczno-biologiczne oraz opracowania językoznawcze i teoriokomunikacyjne. Taki układ doskonale porządkuje zebrane opracowania i ułatwia do nich dostęp.

Do niewątpliwych walorów książki Przemysława Wiatrowskiego, moim zdaniem, należą:

1. Trafny wybór tematu. Tak popularne czasopismo religijne jak „Przewodnik Katolicki” nie doczekało się bowiem do tej pory obszernego i wyczerpującego opracowania lingwistycznego. Prezentowana książka z pewnością tę lukę uzupełnia.

2. Dobór materiału. Analizie poddano (z oczywistych względów) tylko cztery roczniki pisma, jednakże dobór ich nie był przypadkowy. Kluczem były tutaj przede wszystkim czynniki o charakterze historycznym, które z kolei w istotny sposób wpłynęły na interpretację niektórych faktów językowych (np. pozwoliły wskazać główne przyczyny emocjonalnych reakcji nadawców tygodnika).

3. Sposób przedstawienia problemu. Autor rozprawy poświęcił uwagę językowym wykładnikom emocji negatywnych, mając jednak świadomość złożoności zjawisk z zakresu ekspresywności, znacznie poszerzył perspektywę badawczą. W części teoretycznej wyczerpująco nie tylko omówił językowe aspekty emocji, ale także zwrócił uwagę na ich psychologiczne uwarunkowania, starając się (z powodzeniem) uporządkować zawiłą niejednokrotnie terminologię i rozmaite klasyfikacje. Jednocześnie swoje rozważania poparł wnikliwym przeglądem literatury przedmiotu, traktującej o emocjach w perspektywie zarówno językoznawczej, jak i psychologiczno-biologicznej oraz medioznawczej (co zresztą znalazło potwierdzenie w bibliografii umieszczonej na końcu książki).

4. Trafność i skrupulatność przeprowadzonych analiz. Świadczy o tym chociażby fakt, iż autor nie pomija nawet pojedynczych przykładów, które, mimo że odznaczają się niską frekwencją, niewątpliwie zasługują na odnotowanie, a ich pojawienie się w tekście bywa niejednokrotnie znaczące. 
5. Interesujące wyniki przeprowadzonych badań. Wyekscerpowane z materiału jednostki charakteryzują się wieloznacznością ekspresywną - ich wartość emocjonalna najczęściej jest determinowana oddziaływaniami kontekstowymi, które z kolei ukazują wpływ innych emocji. Wśród morfologicznych wykładników negatywnych emocji wynotowanych z tekstów „Przewodnika Katolickiego", jak zauważa autor, najliczniejszą grupę stanowią elementy oznaczające: pogardę, oburzenie, lekceważenie i niezadowolenie. Jako ważny odnotowuje on fakt, iż nierzadko uczucia te współwystępują. Natomiast w obrębie ekspresywizmów leksykalnych najczęściej występujące afekty to: smutek, ból, obawa, niepokój, przerażenie i zdziwienie. O doborze poszczególnych emocjonalizmów decyduje rodzaj manifestowanych uczuć, okazuje się bowiem, że w przypadku emocji skrajnie negatywnych nadawcy chętniej sięgają po elementy ekspresywne, rzadziej po nazwy uczuć. Autor książki tłumaczy ten fakt asekuracyjną postawą nadawców, którzy nie chcą ujawniać swoich emocji w sposób bezpośredni. Zwrócić należy również uwagę na to, iż negatywnej waloryzacji emocjonalnej podlegają najczęściej w „Przewodniku Katolickim" fakty społeczno-polityczne i problemy etyczne, które, ze względu na niezgodność z wyznawanymi na łamach pisma wartościami, nie są aprobowane przez nadawców. Ponadto, zjawiska te nacechowano emocjonalnie ze względu nie na dobro nadawców, lecz na dobro jakiegoś ogółu, jakiejś zbiorowości, do której ci nadawcy należą.

6. Układ pracy i kształt językowo-stylistyczny. Rozprawa odznacza się przejrzystą, klarowną kompozycją - wyraźnie wyeksponowane zostały jej poszczególne elementy, co ułatwia lekturę. Autor sprawnie i poprawnie posługuje się językiem, umiejętnie precyzując rozmaite pojęcia i terminy. Zwraca jednak uwagę skłonność do swoistego żargonu terminologicznego, przez co percepcja tekstu bywa nierzadko utrudniona.

Książka Przemysława Wiatrowskiego to lektura ze wszech miar zajmująca, pojemna treściowo, metodologicznie i problemowo. Z pewnością chętnie po nią sięgną nie tylko językoznawcy, ale również medioznawcy, historycy oraz psychologowie. 